\title{
PENGEMBANGAN BAHAN AJAR BERBENTUK KOMIK MATEMATIKA BERBASIS ANDROID DENGAN PENDEKATAN RME
}

\author{
M. Amirul Latif ${ }^{1}$, Dra. Chusnal Ainy ${ }^{2}$, Achmad Hidayatullah $^{3}$ \\ ${ }^{1,2,3}$ Program studi Pendidikan Matematika, Universitas Muhammadiyah Surabaya \\ Email: 'amirul.latif06@gmail.com, ${ }^{2}$ chusnal.umsby@yahoo.com, ${ }^{3}$ achmadhidayatullah08@gmail.com
}

\begin{abstract}
ABSTRAK
Penelitian ini berawal dari rendahnya aktivitas dan hasil belajar siswa, karena dalam proses pembelajaran di sebabkan oleh pembelajaran matematika yang masih konvensional. Akibatnya, materi pembelajaran tidak bisa tersampaikan dengan baik dan kurang minat siswa membaca materi. Penelitian ini merupakan jenis penelitian pengembangan yang disebut juga dengan istilah Research \& Development $(R \& D)$ dan menggunakan model 4D yang meliputi 4 tahap pendefinisian, perencanaan, pengembangan dan penyebaran. Keempat tahap tersebut pada penelitian ini dibatasi pada tahap pengembangan. Penelitian ini bertujuan untuk mengembangkan bahan ajar berbentuk komik berbasis android dengan pendekatan RME pada materi bangun datar segiempat. Sampel penelitian adalah 27 siswa kelas VII-A SMP Muhammadiyah 15 Surabaya. Data penelitian berupa observasi untuk mengetahui aktivitas siswa dan kemampuan guru dalam mengelola pembelajaran, angket untuk mengetahui respon siswa, dan soal tes berupa essai untuk mengukur kemampuan matematika pada materi segiempat. Hasil kevalidan bahan ajar diperoleh rata-rata 3,67 dengan kategori valid; kepraktisan dengan kriteria dapat digunakan dengan sedikit revisi. keterlaksanaan dalam pembelajaran uji coba terbatas diperoleh 76,85 dengan kriteria baik dan uji coba lapangan diperoleh 91,48 dengan kriteria sangat baik; efektifitas bahan ajar dinyatakan dari hasil respon siswa $92,75 \%$ dengan kriteria sangat kuat, ketuntasan klasikal sebesar $74,07 \%$ dan pada uji coba lapangan ketuntasan klasikal sebesar $88,89 \%$.
\end{abstract}

Kata Kunci: Bangun Datar Segiempat, Komik, Android, Pengembangan, RME

\begin{abstract}
This research starts from the low activity and student learning outcomes, because the learning process is caused by the learning of mathematics that is still conventional. As a result, learning material cannot be conveyed properly and students lack interest in reading the material. This research is a type of development research which is also called the Research \& Development (R\&D) and uses a 4D model which includes 4 stages of defining, planning, developing and disseminating. The four stages in this study are limited to the development stage. This study aims to develop teaching materials in the form of android-based comics with the RME approach to rectangular flat material. The research sample was 27 students of class VII-A SMP 15 Muhammadiyah Surabaya. Research data in the form of observations to determine student activity and the ability of teachers to manage learning, questionnaires to determine student responses, and test questions in the form of essays to measure mathematic abilities on quadrilateral. The validity results of teaching materials obtained an average of 3,67 with a valid category; practicality with criteria can be used with a little revision. feasibility in learning limited trials obtained 76,5 with good criteria and field trials obtained 91,48 with very good criteria; the effectiveness of teaching materials is expressed from the results of $92,75 \%$ student responses with very strong criteria, classical completeness is $74,07 \%$ and in classical mastery field trials is $88,89 \%$.
\end{abstract}

Keywords: Android, Comics, Quadrilateral, Development, RME 


\section{PENDAHULUAN}

Menurut Wahyuni (2016) pendidikan merupakan faktor penting yang diibaratkan suatu investasi sumber daya manusia. Menurut Soyokmukti (2015) pendidikan adalah proses untuk memberikan manusia berbagai macam situasi yang bertujuan memberdayakan diri. Berdasarkan pendapat para ahli di atas dapat disimpulkan pendidikan adalah faktor yang sangat penting dalam kehidupan yang bertujuan dalam pemberdayaan manusia.

Pemanfaatan teknologi dalam proses pembelajaran masih minim sehingga membuat kualitas pendidikan yang dilaksanakan dalam penyampaian materi dan pemanfaatan media masih kurang. Melalui hal ini media pembelajaran yang digunakan oleh tenaga pendidik terutama guru sangat mempengaruhi motivasi, minat, sekaligus hasil belajar peserta didik, menurut Anisa (2017).

Menurut Herawati (2015) bahan ajar adalah materi yang disusun secara sistematis yang digunakan untuk membantu guru dalam melaksanakan kegiatan belajar mengajar sehingga tercipta lingkungan atau suasana yang memungkinkan siswa untuk belajar. Menurut Tarigan (2006) bahan ajar merupakan seperangkat materi yang disusun secara sistematis baik tertulis maupun tidak sehingga tercipta lingkungan / suasana yang memungkinkan siswa untuk belajar. Bahan ajar yang digunakan disekolah masih menggunakan buku dan lembar kerja siswa dan masih kurangnya kreatif untuk bahan ajar yang digunakan sehinggga siswa merasa bosan. Kurangnya minat belajar siswa pada pelajaran matematika karena bahan ajar yang digunakan masih minim dan tidak inovasi.

Menurut Athoillah, M (2013) android merupakan sistem operasi untuk telepon berbasis kernel linux, dimana Google mengibaratkan android sebagai tumpukan software, setiap tumpukan yang berisi untuk mendukung fungsi spesifik dari sistem operasi. Menurut Ichwan, M (2011) android merupakan sebuah sistem operasi untuk perangkat mobile berbasis operasi, middleware, dan juga aplikasi. Android menyediakan platform_terbuka bagi para pengembang untuk membuat aplikasi mereka sendiri.

Menurut beberapa penjelasan diatas tentang android, dapat disimpulkan bahwa android merupakan sistem operasi untuk telepon, perangkat mobile berbasis operasi middleware dan aplikasi.

Berbicara pembelajaran berdasarkan pengamatan yang dilakukan oleh peneliti di SMP Muhammadiyah 15 Surabaya. Rendahnya keaktifan dan hasil belajar dalam pembelajaran matematika yang dialami kelas VII-A disebabkan oleh beberapa faktor diantaranya pembelajaran matematika yang masih konvensional dimana guru mengajar hanya dengan metode ceramah. Guru sebagai pusat belajar mengajar sehingga siswa kurang aktif dan kurang rajin dalam mengerjakan latihan-latihan soal yang diberikan guru. Sehingga siswa hanya menerima apa yang diberikan guru, faktor lainnya adalah faktor bahan ajar yang dimiliki siswa kurang menarik dan kurang lengkap sehingga materi pembelajaran tidak bisa tersampaikan dengan baik dan kurang minat siswa membaca materi yang tersedia di dalam bahan ajar yang dimilki. Bahan ajar yang kurang menarik dan kurangnya minat siswa dalam mempelajari bahan ajar akan membuat siswa kurang memahami apa yang dipelajari dan tidak bisa mengikuti pembelajaran dengan baik. Buku teks dan LKS (Lembar Kerja Siswa) yang digunakan di sekolah masih tergolong buku teks dan LKS yang sudah tersedia dari penerbit sehingga mempermudah siswa untuk mengikuti kegiatan pembelajaran, akan tetapi buku dan LKS yang ada, kurang menarik siswa untuk lebih aktif belajar sehingga siswa kurang minat belajar. Faktor selanjutnya karena kecanggihan dari smartphone android saat ini sudah sangat membantu dalam pendidikan, pada siswa - siswi SMP Muhammadiyah 15 Surabaya, namun kecanggihan smartphone android banyak yang belum memanfaatkan dengan baik. Kebanyakan siswa-siswi menggunakan untuk bermain game online.

Kenyataan selama ini terjadi dalam proses pembelajaran matematika adalah sebagian besar siswa berpandangan bahwa pelajaran matematika merupakan mata pelajaran yang membosankan. Hal tersebut disebabkan karena dalam proses pembelajaran matematika siswa tidak dilibatkan secara aktif dan proses pembelajaran lebih fokus kepada guru (Shoffa, 2009). Oleh karena itu hasil belajar yang kurang efektif tersebut perlu ditingkatkan dan perlu menggunakan bahan ajar yang lebih inovatif.

Salah satu cara agar suasana belajar yang menyenangkan, menarik, dan mengesankan dengan pembelajaran yang kreatif dan inovatif salah satunya yaitu dengan menggunakan bahan ajar. Bahan ajar yang menarik, kreatif dan inovatif yang dapat membantu siswa untuk lebih aktif, dalam menerima materi, berlatih, serta memahami materi dalam bentuk nyata. Terdapat beberapa bahan ajar yang digunakan dalam pembelajaran, terdiri dari modul, koran, handout, majalah, buku teks dan komik. 
Salah satu inovasi dalam pembelajaran matematika yaitu mengembangkan bahan ajar berbentuk komik berbasis android.

Menurut Rahmanadji (2018), komik merupakan alat komunikasi massa yang menggabungkan konsepsi khayalan dan pandangan tentang kehidupan nyata yang dianggap sesuai dengan masyarakat luas, komik menyuguhkan dunia gambar secara melimpah, dimana rangkaian gambar yang disusun untuk menggambarkan suatu cerita, selain gambar sebagian dari komik dilengkapi dengan teks yang ditampilkan sebagai dialog maupun sekedar gambar.

Penggunaan komik matematika berbasis android dalam pembelajaran disekolah sebaiknya menggunakan pendekatan mengajar, sehingga komik dapat menjadi alat atau bahan pembelajaran siswa. salah satu pendekatan pembelajaran yang mampu menjadikan siswa berlatih untuk mencapai dan meningkatkan pemahaman siswa dalam pembelajaran matematika adalah pendekatan RME (Realistic Mathematic Education). Menurut Tarigan (2006) pendekatan RME merupakan pendekatan yang ditujukan untuk pengembangan pola pikir praktis, logis, kritis, dan jujur dengan berorientasi pada penalaran matematika dalam menyelesaikan masalah. Pendidikan harus mengarahkan siswa untuk mengaplikasikan matematika dalam situasi dan kesempatan di kehidupan sehari-hari dengan cara sendiri. Pendekatan RME (Realistic Mathematic Education) merupakan suatu pendekatan yang menjanjikan dalam pembelajaran matematika. Peneliti mencoba mengembangkan bahan ajar berupa komik berbasis android pada pelajaran matematika di kelas VII SMP Muhammadiyah 15 Surabaya. Bahan ajar komik matematika berbasis android yang dikembangkan sesuai dengan karakteristik siswa yang kurang minat pada pelajaran matematika.

\section{METODE}

Penelitian ini merupakan jenis penelitian pengembangan yang disebut juga dengan istilah Research \& Development $(R \& D)$. Pada penelitian ini, peneliti mengembangkan bahan ajar berbentuk komik berbasis android sebegai bahan pembelajaran matematika pada siswa kelas VII untuk materi pokok bangun datar segiempat.

Tempat penelitian tentang efektivitas pembelajaran matematika menggunakan bahan ajar berbentuk komik berbasis android dilaksanakan di SMP Muhammadiyah 15 Surabaya di Jl. Platuk No.104, Sidotopo Wetan, Kenjeran, Surabaya. Waktu penelitian dilakukan pada semester genap pada tahun ajaran 2018/2019 yang berlangsung pada bulan Maret 2019.

Pada penelitian ini menggunakan model pengembangan 4D yang dikemukakan pendapat oleh Hamdani (2011) model pengembangan ini terdapat 4 tahap dalam pelaksanaannya yaitu Pendefinisian (Define), Perancangan (Design), Pengembangan (Develop). Namun dalam penelitian ini tidak menerapkan tahap Penyebaran (Disseminate) sehingga hanya sampai tahap pengembangan (Develop) karena keterbatasan waktu penelitian.

Adapun instrument penelitian yang digunakan dalam penelitian ini adalah sebagai berikut.

a. Lembar validasi bahan ajar berbentuk komik berbasis android.

Lembar validasi ini digunakan untuk memperoleh data tentang penilaian dari para ahli terhadap bahan ajar berbentuk komik yang dikembangkan. Hasil penilaian ini dijadikan dasar untuk perbaikan produk sebelum diuji cobakan. Setelah lembar divalidasi oleh ahli. Lembar validasi bahan ajar berbentuk komik berbasis android terdiri dari lembaran penilaian kelayakan bahan ajar yang akan digunakan untuk siswa.

b. Lembar pengamatan keterlaksanaan pembelajaran guru dan aktivitas siswa menggunakan bahan ajar berbentuk komik berbasis android dengan pendekatan RME.

Lembar pengamatan keterlaksanaan pembelajaran dengan pendekatan RME digunakan untuk mendapatkan data berupa keterlaksanaan pembelajaran guru dan aktivitas siswa selama proses pembelajaran menggunakan bahan ajar berbentuk komik berbasis android yang dikembangkan. Pengamatan ini untuk mengamati keterlakasanaan pembelajaran oleh guru dan siswa menggunakan bahan ajar berbentuk komik berbasis android dengan pendekatan RME. Teknik yang digunakan adalah dengan menggunakan RPP yang menggunakan pendekatan RME dan lembar pengamatan keterlaksanaan pembelajaran menggunakan bahan ajar berbentuk komik berbasis android dengan pendekatan RME pada pengamat. Selama pembelajaran berlangsung, pengamat langsung mengisi lembar pengamatan pembelajaran adalah dengan memberikan tanda centang $(\sqrt{ })$ dan mengisi jumlah 
siswa berdasarkan skala penilaian pada kolom yang tersedia di lembar pengamatan keterlaksanaan pembelajaran dengan pendekatan RME.

c. Tes hasil belajar.

Tes hasil belajar yang berupa tes soal yang digunakan untuk memperoleh data hasil belajar siswa dalam pembelajaran matematika dengan materi geometri transformasi dengan menggunakan bahan ajar berbentuk komik berbasis android.

d. Lembar angket respon siswa.

Lembar angket respon siswa digunakan untuk mengetahui respon siswa terhadap penggunakan bahan ajar berbentuk komik berbasis android pada mata pelajaran matematika materi geometri transformasi.

Data yang diperoleh dalam penelitian akan dianalisis untuk digunakan merevisi bahan ajar berbentuk komik berbasis android yang baik sesuai dengan kriteria yang ditetapkan. Berikut merupakan rangkaian kegiatan analisis data untuk kriteria pengembangan bahan ajar berbentuk komik berbasis android.

Tabel 1. Kegiatan Analisis Data untuk Kriteria Pengembangan Bahan Ajar berbentuk Komik berbasis Android

\begin{tabular}{|c|c|c|c|c|c|c|}
\hline $\begin{array}{c}\text { Tujuan } \\
\text { penilaian }\end{array}$ & Indikator & Instrumen & $\begin{array}{c}\text { Sumber } \\
\text { data }\end{array}$ & $\begin{array}{l}\text { Data yang } \\
\text { diperoleh }\end{array}$ & $\begin{array}{c}\text { Teknik } \\
\text { analisis } \\
\text { data }\end{array}$ & $\begin{array}{c}\text { Kriteria yang } \\
\text { diinginkan }\end{array}$ \\
\hline \multirow[t]{2}{*}{ Kevalidan } & $\begin{array}{l}\text { Komponen Bahan } \\
\text { Ajar berbentuk } \\
\text { Komik berbasis } \\
\text { Android dengan } \\
\text { pendekatan RME } \\
\text { dengan masalah } \\
\text { pada kehidupan } \\
\text { nyata sesuai } \\
\text { dengan materi }\end{array}$ & $\begin{array}{l}\text { Lembar } \\
\text { validasi bahan } \\
\text { ajar berbentuk } \\
\text { komik berbasis } \\
\text { android }\end{array}$ & $\begin{array}{l}\text { Dua } \\
\text { orang } \\
\text { ahli }\end{array}$ & $\begin{array}{l}\text { Skor nilai } \\
\text { validasi }\end{array}$ & $\begin{array}{l}\text { Menentukan } \\
\text { rata-rata } \\
\text { validasi } \\
\text { oleh } 4 \text { orang } \\
\text { ahli }\end{array}$ & $\begin{array}{l}\text { Bahan ajar } \\
\text { berbetuk } \\
\text { komik } \\
\text { berbasis } \\
\text { android valid } \\
\text { jika hasil } \\
\text { validasi dari } \\
\text { validator } \\
R T V \geq 3\end{array}$ \\
\hline & $\begin{array}{l}\text { Bahan ajar } \\
\text { berbentuk komik } \\
\text { berbasis android } \\
\text { dinyatakan layak } \\
\text { digunakan }\end{array}$ & $\begin{array}{l}\text { Lembar } \\
\text { validasi bahan } \\
\text { ajar berbentuk } \\
\text { komik berbasis } \\
\text { android }\end{array}$ & $\begin{array}{l}\begin{array}{l}\text { Dua } \\
\text { orang }\end{array} \\
\text { ahli } \\
\text { (ahli } \\
\text { media } \\
\text { dan ahli } \\
\text { materi) }\end{array}$ & $\begin{array}{l}\text { Kriteria yang } \\
\text { didapat }\end{array}$ & $\begin{array}{l}\text { Menentukan } \\
\text { kelayakan } \\
\text { penggunaan }\end{array}$ & $\begin{array}{l}\text { Bahan ajar } \\
\text { berbentuk } \\
\text { komik } \\
\text { berbasis } \\
\text { android } \\
\text { praktis jika } \\
\text { validator } \\
\text { memberikan } \\
\text { simpulan } \\
\text { "layak } \\
\text { digunakan" } \\
\end{array}$ \\
\hline \multirow[t]{2}{*}{ Kepraktisan } & $\begin{array}{l}\text { Keterlaksanaan } \\
\text { pembelajaran } \\
\text { sesuai dengan } \\
\text { RPP }\end{array}$ & $\begin{array}{l}\text { Lembar } \\
\text { keterlaksanaan } \\
\text { pembelajaran }\end{array}$ & $\begin{array}{l}\begin{array}{l}\text { Dua } \\
\text { orang }\end{array} \\
\text { ahli } \\
\text { (ahli } \\
\text { media } \\
\text { dan ahli } \\
\text { materi) }\end{array}$ & $\begin{array}{l}\text { Skor hasil } \\
\text { dari } \\
\text { pengamatan } \\
\text { diberikan }\end{array}$ & $\begin{array}{l}\text { Menentukan } \\
\text { rerata oleh } 3 \\
\text { oserver }\end{array}$ & $\begin{array}{l}\text { Bahan ajar } \\
\text { berbentuk } \\
\text { komik } \\
\text { berbasis } \\
\text { android } \\
\text { praktis jika } \\
\text { hasil lembar } \\
\text { keterlaksanaan } \\
\text { pembelajaran } \\
R K \geq 2,50\end{array}$ \\
\hline & $\begin{array}{l}\text { Observasi } \\
\text { Aktivitas Siswa }\end{array}$ & $\begin{array}{l}\text { Lembar } \\
\text { observasi } \\
\text { aktivitas siswa }\end{array}$ & $\begin{array}{l}\text { Dua } \\
\text { orang } \\
\text { ahli } \\
\text { (ahli } \\
\text { media } \\
\text { dan ahli } \\
\text { materi) }\end{array}$ & $\begin{array}{l}\text { Skor hasil } \\
\text { dari } \\
\text { observasi } \\
\text { aktivitas } \\
\text { siswa }\end{array}$ & $\begin{array}{l}\text { Menentukan } \\
\text { rerata oleh } 3 \\
\text { pengamat }\end{array}$ & $\begin{array}{l}\text { Aktivitas } \\
\text { siswa jika } \\
\text { hasil dari } \\
\text { pengamat } \\
\text { menghasilkan } \\
\text { nilai rata-rata } \\
\text { sesuai dengan } \\
\text { kategori maka }\end{array}$ \\
\hline
\end{tabular}




\begin{tabular}{|c|c|c|c|c|c|c|}
\hline $\begin{array}{c}\text { Tujuan } \\
\text { penilaian }\end{array}$ & Indikator & Instrumen & $\begin{array}{c}\text { Sumber } \\
\text { data }\end{array}$ & $\begin{array}{l}\text { Data yang } \\
\text { diperoleh }\end{array}$ & $\begin{array}{c}\text { Teknik } \\
\text { analisis } \\
\text { data }\end{array}$ & $\begin{array}{c}\text { Kriteria yang } \\
\text { diinginkan }\end{array}$ \\
\hline & & & & & & $\begin{array}{l}\text { dinyatakan } \\
\text { "aktif" }\end{array}$ \\
\hline \multirow[t]{2}{*}{ Keefektifan } & $\begin{array}{l}\text { Hasil tes belajar } \\
\text { di atas KKM } \\
\text { sekolah }\end{array}$ & Lembar soal & Siswa & $\begin{array}{l}\text { Skor hasil } \\
\text { tes belajar }\end{array}$ & $\begin{array}{l}\text { Menentukan } \\
\text { rerata nilai } \\
\text { siswa }\end{array}$ & $\begin{array}{l}\text { Bahan ajar } \\
\text { berbentuk } \\
\text { komik } \\
\text { berbasis } \\
\text { android efektif } \\
\text { jika hasil nilai } \\
\text { tes belajar } \\
\text { siswa di atas } \\
\text { KKM yang } \\
\text { ditentukan } \\
\text { pihak sekolah }\end{array}$ \\
\hline & $\begin{array}{l}\text { Respon siswa } \\
\text { positif terhadap } \\
\text { bahan ajar } \\
\text { berbentuk komik }\end{array}$ & $\begin{array}{l}\text { Lembar angket } \\
\text { respon siswa }\end{array}$ & Siswa & Skor angket & $\begin{array}{l}\text { Menentukan } \\
\text { hasil respon } \\
\text { siswa }\end{array}$ & $\begin{array}{l}\text { Bahan ajar } \\
\text { berbentuk } \\
\text { komik } \\
\text { bernasis } \\
\text { android efektif } \\
\text { jika hasil } \\
\text { respon positif } \\
\text { siswa }>70 \%\end{array}$ \\
\hline
\end{tabular}

\section{HASIL}

Hasil uji coba bahan ajar berbentuk komik berbasis android dengan pendekatan RME di SMP Muhammadiyah 15 Surabaya diperoleh data sebagai berikut.

Pertama, keterlaksanaan pembelajaran yang dilakukan oleh 1 observer pada guru matematika kelas VII-A SMP Muhammadiyah 15 Surabaya didapat rata-rata total sebesar 3,75 dengan kriteria sangat baik. Kedua, ketuntasan belajar siswa disesuaikan dengan KKM di SMP Muhammadiyah 15 Surabaya yaitu 75 untuk mata pelajaran matematika siswa yang telah tuntas sebanyak 24 siswa dan siswa yang tidak tuntas sebanyak 3 siswa, dengan persentase ketuntasan belajar sebesar 88,89\% dan rata-rata hasil tes belajar siswa 91,48 \%. Ketiga, Respon siswa kelas VII-A di SMP Muhammadiyah 15 Surabaya dengan sebanyak 27 siswa diperoleh rata-rata 92,75\% termasuk kriteria sangat kuat.

Dalam penelitian ini, bahan ajar berbentuk komik berbasis android dikatakan layak jika telah memenuhi 3 syarat kelayakan yaitu valid, praktis dan efektif. Penilaian terhadap bahan ajar berbentuk komik dinilai oleh dua validator yaitu validator ahli bahan ajar dan ahli materi.

Terdapat satu aspek penilaian yang dinilai oleh dua validator ahli bahan ajar, dapat dilihat penilaian dari 2 validator terhadap aspek ilustrasi memperoleh rata-rata 3,67 termasuk dalam kriteria "valid". Aspek ilustrasi terdapat 7 butir aspek yaitu (1) kesederhanaan, (2) kesatuan/keterpaduan, (3) penekanan, (4) keseimbangan, (5) bentuk, (6) garis, (7) warna. Dua validator ahli bahan ajar menilai untuk mengganti tampilan pada cover depan komik agar lebih menarik.

Bagian bahan ajar berbentuk komik yang direvisi dan diperbaiki dapat dilihat pada gambar 1 sebagai berikut: 

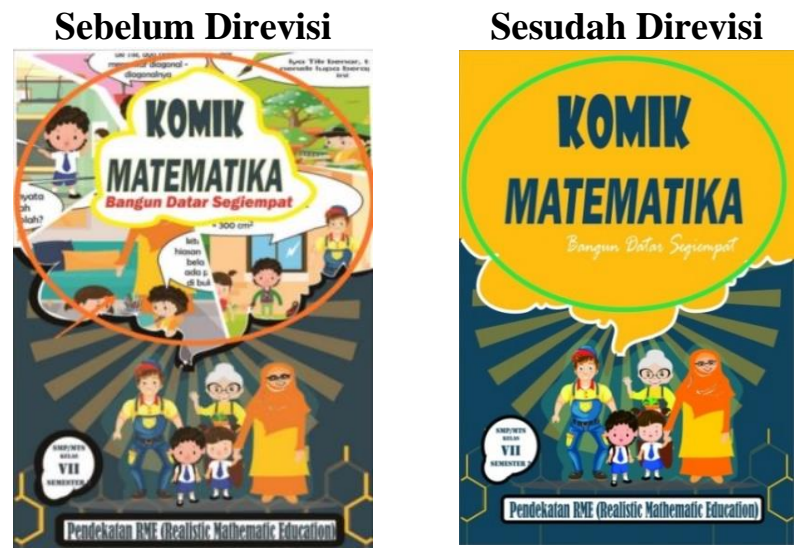

Gambar 1. Bahan ajar komik yang direvisi

Saran yang diberikan validator menghilangkan gambar dialognya pada kofer

Dua validator ahli materi menilai tiga aspek format, bahasa, dan isi, dapat dilihat penilaian dari 2 validator terhadap aspek format pada komik memperoleh rata-rata 3,8 termasuk dalam kriteria "valid". Aspek bahasa pada komik memperoleh rata-rata 3,67 termasuk kriteria "valid". Pada aspek isi pada pada komik memperoleh rata-rata 3,6 termasuk dalam kriteria "valid". Dari ketiga aspek yang dinilai oleh ahli materi mendapatkan rata-rata 3,69 termasuk dalam kriteria "valid". Dari dua validator ahli materi menilai untuk memperbaiki penulisan pada pembahasan soal materi yang digunakan pada bahan ajar berbentuk komik.

Bagian bahan ajar berbentuk komik yang direvisi dan diperbaiki dapat dilihat pada tabel sebagai berikut.
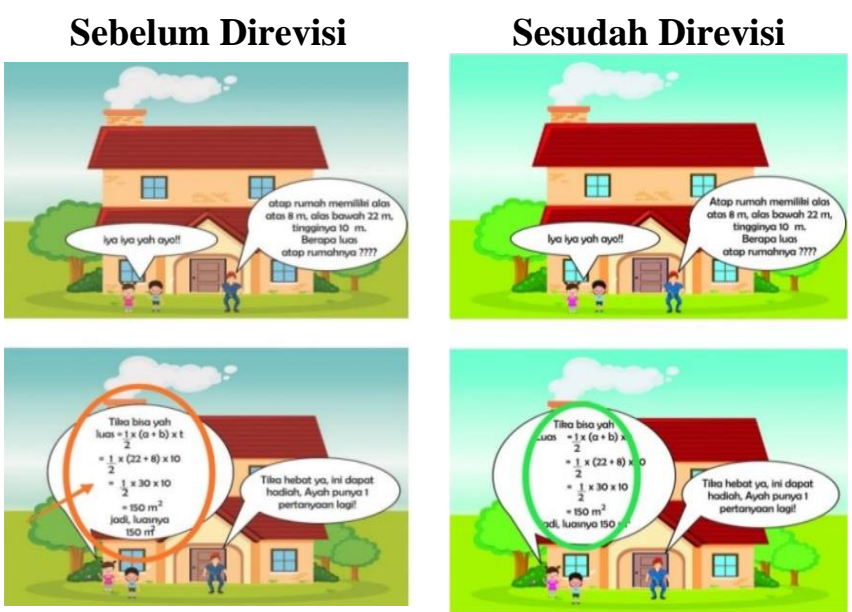

Gambar 2. Materi pada komik yang direvisi

Saran yang diberikan validator merapikan penulisan urutan peletakan $(=)$ secara lurus dan rapi

Ditinjau dari efektivitas produk hasil tes peserta didik yang telah melaksanakan pembelajaran menggunakan bahan ajar komik berbasis android dengan pendekatan RME pada VII-A SMP Muhammadiyah 15 Surabaya diperoleh ketuntasan 88,89\%. Respon siswa terhadap bahan ajar komik berbasis android yang dikembangkan diperoleh sebesar 92,75\% yang memenuhi kriteria "sangat kuat" sehingga respon peserta didik terhadap penggunaan bahan ajar komik dengan pendekatan kontekstual adalah positif.

Kepraktisan RPP dilihat dari penilaian umum oleh tiga validator dan keterlaksanaan pembelajaran dilapangan. Validator ke-1 menyatakan RPP ini dalam kriteria B yang artinya layak 
diujicobakan di lapangan setelah direvisi sesuai saran. Validator ke-2 menyatakan RPP ini dalam kriteria B yang artinya layak diujicobakan dilapangan setelah direvisi sesuai saran.

Ditinjau dari keterlaksanaan pembelajaran yang diamati oleh observer pada guru kelas VII-A SMP Muhammadiyah 15 Surabaya waktu proses pembelajaran yang menggunakan pendekatan RME diperoleh 3.95 dengan kriteria "sangat baik".

\section{PEMBAHASAN}

Adapun pembahasan bahan ajar berbentuk komik berbasis android dengan pendekatan RME yang dikembangkan setelah diteliti pada lapangan sebagai berikut.

1. Deskripsi Bahan Ajar Berbentuk Komik

Bahan ajar berbentuk komik ini termasuk jenis komik strip yaitu komik yang disajikan dalam rangkaian gambar yang disajikan secara singkat dan berseri di setiap edisi atau tahapannya secara teratur dan rasa keingintahuan pembaca dibawa untuk verita selanjutnya. Komik ini juga termasuk dalm kategori komik online dimana komik ini lebih menguntungkan, selain biaya relative murah dan lebih mudah dalam menyebar luaskan komik online yang dapat dibaca oleh siapa saja. Bahan ajar berbentuk komik berbasis android terdapat 44 slide yang berisi kofer, pilihan tombol, nama tokoh, petunjuk, percakapan, masalah, rangkuman materi, contoh soal, dan latihan soal. Percakapan dalam komik berfungsi sebagai alat bantu siswa dalam mengerjakan masalah-masalah dan membantu siswa dalam memahami materi bangun datar segiempat. Bahan ajar komik berbasis android yang dikembangkan peneliti menggunakan format ukuran desain 1,280 × 720 pixel, menggunakan warna yang cerah untuk mewarnai gambar pada desain komik. Menggunakan font semi formal agar tulisan lebih menarik sehingga mengajak siswa santai dalam belajar. Uraian penjelasan masukan perbaikan validator pada bahan ajar berbentuk komik berbasis android dengan pendekatan RME sebagai alat bantu bahan ajar berbentuk komik yang dikembangkan. Berdasarkan kevalidan bahan ajar berbetuk komik berbasis android dapat disimpulkan bahwa bahan ajar berbetuk komik berbasis android yang dikembangkan valid. Sebagaimana menurut Amalia (2011), menyebutkan bahwa ada beberapa aspek kevalidan bahan ajar sebagai berikut: (1) Segi format yaitu setiap bagian disajikan secara jelas, menunjukan pertimbangan antara teks dan ilustrasi, secara visual cukup menarik dan menggunakan struktur kalimat yang jelas dan sederhana. (2) Segi bahasa yaitu bahasa yang digunakan sesuai dengan kemampuan siswa agar mudah dipahami, menggunakan pilihan kata yang jelas dan sederhana, dan menggunakan struktur kalimat yang jelas dan sederhana. (3) Segi ilustrasi yaitu jelas, mudah dimengerti, mendukung agar konsep mudah dipahami, dan berhubungan dengan lingkungan siswa. (4) Segi isi yaitu memuat informasi penting yang terkait, bagian-bagian tersusun secara logis, serta kebenaran isi.

2. Penggunaan Bahan Ajar Berbentuk Komik

Bahan ajar berbentuk komik berbasis android digunakan untuk kelas VII semester genap, pada materi bangun datar segiempat yang meliputi: (1) materi pada komik mengenal benda-benda yang berbentuk segiempat dalam kehidupan sehari-hari pada 8 slide pada tahap pertama dan terdapat percakapan yang akan membantu siswa untuk menyelesaikan masalah tahap 1 pada slide ke 8 di slide tahap pertama. (2) sub materi pada komik mengenai bangun datar persegi panjang yang terdapat percakapan yang akan membantu siswa untuk menyelesaikan masalah tahap 2 pada slide ke 6 pada slide tahap kedua. (3) materi pada komik mengenai bangun datar persegi yang terdapat percakapan menyelesaikan masalah tahap ke 3 pada slide ke 5 pada tahap ketiga. (4) sub materi pada komik mengenai bangun datar jajargenjang yang terdapat percakapan menyelesaikan masalah tahap ke 4 pada slide ke 4 pada tahap keempat. (5) sub materi pada komik mengenai bangun datar belah ketupat yang terdapat percakapan menyelesaikan masalah tahap ke 5 pada slide ke 4 pada slide kelima. (6) sub materi pada komik mengenai bangun datar trapesium yang terdapat percakapan menyelesaikan masalah tahap ke 6 pada slide keenam. (7) sub materi pada komik mengenai bangun datar layanglayang yang terdapat percakapan menyelesaikan masalah tahap ke 6 pada silde ketujuh. (8) setiap tahap atau sub materi pada komik terdapat rangkuman dan contoh soal untuk memperkuat pengetahuan siswa. (9) setiap tahap atau sub materi pada komik terdapat latihan soal yang akan dikerjakan siswa secara individu setelah mereka menyelesaikan masalah yang terdapat pada sub materi.

3. Kelebihan Bahan Ajar Berbentuk Komik 
Berdasarkan pengematan pada proses penelitian diperoleh kelebihan bahan ajar berbentuk komik berbasis android dengan pendekatan RME. Pertama, bahan ajar berbentuk komik berbasis android dengan pendekatan RME dapat membuat siswa lebih aktif dan dapat berfikir tingkat tinggi, hal ini dapat dilihat dari siswa pada saat membaca komik atau percakapan yang ada dalam bahan ajar dan mengerjakan permasalahan yang ada pada komik. Sehingga guru disini berfungsi sebagai fasilitator dan siswa adalah yang mencari atau yang menemukan. Kedua, bahan ajar berbentuk komik berbasis android dengan pendekatan RME dapat mengaplikasikan materi dalam permasalahan kehidupan sehari-hari sehingga materi tidak terlihat abstrak. Ketiga, bahan ajar berbentuk komik berbasis android dengan pendekatan RME dikembangkan dalam skala lebih luas, presentase tingkat keberhasilan menggunakan bahan ajar berbentuk komik meningkat dari 74,07 \% meningkat menjadi $88,89 \%$.

Sebagaimana menurut Daryanto (2010) adalah penyajian mengandung unsur visual cerita dan cerita yang kuat. Dimana ekspresi yang divisualisasikan akan membuat pembaca terlibat secara emosional sehingga membuat pembaca terlibat secara emosional sehingga membuat pembaca untuk terus membacanya hingga selesai. Komik yang berisikan materi-materi pelajaran akan membuat siswa tidak bosan dan dapat memahami materi yang pelajari.

4. Kekurangan Bahan Ajar Berbentuk Komik

Bahan ajar berbentuk komik berbasis android dengan pendekataan RME juga memiliki kekurangan yaitu proses pembuatan yang memerlukan waktu lama dan hanya dapat digunakan menggunakan pendekatan RME dan PMRI. Kemudian kemudahan siswa membaca komik dapat membuat malas membaca buku yang tidak bergambar sehingga menyebabkan penolakan-penolakan atas buku yang tidak bergambar. Sebagaimana menurut Feriyanto (2012) kekurangan dari komik terdiri dari beberapa kekurangan, yaitu pertama, guru harus menggunakan motivasi potensial dari komik, tetapi jangan berhenti disitu saja, jika minat baca siswa sudah meningkat, cerita bergambar dilengkapi oleh materi bacaan, gambar, foto, percobaan serta kegiatan lainnya yang lebih kreatif. Kedua kemudahan siswa membaca komik dapat membuat malas membaca buku yang tidak bergambar sehingga menyebabkan penolakan-penolakan atas buku yang tidak bergambar.

\section{SIMPULAN DAN SARAN}

Bedasarkan hasil penelitian pengembangan ini proses pengembangan bahan ajar berbetuk komik berbasis android dengan pendekatan RME di SMP Muhammadiyah 15 Surabaya menggunakan model pengembangan 4D model pengembangan ini terdapat 4 tahap dalam pelaksanaannya yaitu Pendefinisian (Define), Perancangan (Design), Pengembangan (Develop) dan tidak menerapkan tahap Penyebaran (Disseminate) sehingga hanya sampai tahap pengembangan (Develop).

Adapun hasil pengembangan bahan ajar berbenuk komik berbasis android pada penelitian ini menghasilkan bahan ajar berbentuk komik dengan pendekatan RME yang di uji terbatas pada kelas VII-B SMP Muhammadiyah 15 Surabaya dan uji coba lapangan pada kelas VII-A SMP Muhammadiyah 15 Surabaya. Maka hasil penelitian ini dapat dilihat pada kualitas bahan ajar berbentuk komik berbasis android yang dihasil sebagai berikut.

a. Ditinjau dari kevalidan bahan ajar berbentuk komik berbasis android.

Berdasarkan penilaian terhadap bahan ajar berbentuk komik dengan pendekatan RME dari dua validator menilai tujuh aspek yang terdiri dari kesederhanaan, kesatuan/keterpaduan, penekanan, keseimbangan, bentuk, garis, dan warna diperoleh rata-rata 3.67 dengan kategori "valid". Oleh karena itu bahan ajar berbentuk komik berbasis android dengan pendekatan RME dinilai dari aspek kevalidannya dinyatakan valid.

b. Ditinjau dari kepraktisan bahan ajar berbentuk komik berbasis android

Menentukan kepraktisan bahan ajar berbentuk komik dengan pendekatan RME dilihat berdasarkan penilaian umum dari kedua validator. Dua validator menyatakan kriteria B yang artinya dapat digunakan dilapangan dengan sedikit revisi.

Keterlaksanaan pembelajaran yang diamati satu observer pada guru kelas VII-B di SMP Muhammadiyah Surabaya diperoleh 3,6 dengan kriteria baik. Sedangkan dikembangkan dengan skala lebih luas pada Kelas VII-A SMP Muhammadiyah 15 Surabaya keterlaksanaan pembelajaran 
diperoleh 3,75 dengan kriteria sangat baik. Berdasarkan penilaian dari kedua validator dan keterlaksanaan pembelajarn yang diamati oleh tiga observer dapat disimpulkan bahwa bahan ajar berbentuk komik berbasis android dengan pendekatan RME praktis.

c. Ditinjau dari efektifitas bahan ajar berbentuk komik berbasis android

Tes hasil belajar siswa yang telah melaksanakan pembelajaran menggunakan bahan ajar berbentuk komik berbasis android dengan pendekatan RME pada sekolah kelas VII-B SMP Muhammadiyah 15 Surabaya diperoleh ketuntasan sebesar 74,07 \%. Respon siswa terhadap bahan ajar berbentuk komik berbasis android yang dikembangkan diperoleh sebesar 85,19 \% yang termasuk dalam kriteria "sangat kuat". Sedangkan dilakukan uji coba lapangan di kelas VII-A SMP Muhammadiyah 15 Surabaya diperoleh ketuntasan klasikal tes hasil belajar sebesar 88,89\%. Respon siswa terhadap bahan ajar berbentuk komik yang dikembangkan diperoleh $92,75 \%$ yang termasuk dalam kriteria "sangat kuat".

\section{DAFTAR RUJUKAN}

Amalia, M. (2011). Pengembangan buku ajar dan lembar kerja siswa (LKS) dengan media komik pada materi jaring-jaring Kubus dan balok. Surabaya: Universitas Muhammadiyah Surabaya.

Anisa, R. (2017). Pengembangan media komik berbasis android pada pokok bahasa gerak lurus untuk SMP Kelas VII. Lampung: Universitas Islam Negeri Raden Intan Lampung

Athoillah, M, I. (2013). Perencanaan sistem informasi mobile berbasis android untuk kontrol persediaan barang di gudang. Jurnal sains dan seni pomits, 2.

Feriyanto. (2012). Pengembangan lembar kerja siswa (LKS) berbentuk komik untuk meningkatkan komunikasi matematika siswa pada materi keliling dan luas daerah segitiga di SMP Negeri 1 Mojokerto. Mojokerto: Universitas Muhammadiyah Surabaya.

Hamdani. (2011). Strategi belajar mengajar. Bandung: CV Pustaka Setia.

Herawati, L. (2015). Pengembangan bahan ajar matematika menggunakan aplikasi mind map di SMP Negeri 3. Cirebon: Kementrian Institut Agama Islam Negeri Syekh Nurjati.

Ichwan, M, D. (2011). Pengukuran kinerja goodreads application programming interface (API) pada aplikasi mobile android. Institut Teknologi Bandung, 02.

Rahmanadji, D. (2018). Awal eksistensi komik Indonesia, sebagai produk budaya nasional. Universitas Negeri Malang.

Shoffa, S. (2009). Pengembangan perangkat pembelajaran matematika dengan pendekatan PMR pada pokok bahasan jajargenjang dan belah ketupat. Didaktis.

Soyokmukti, N. . (2015). Teori-teori pendidikan. Yogyakarta: AR- RUZZ Media.

Sutisna, A, P. (2016). Meningkatkan pemahaman matematis melalui pendekatan tematik dengan RME. Sumedang: Program Studi PGSD UPI Kampus Sumedang.

Tarigan, D. (2006). Pembelajaran matematika realistik. Jakarta: Depdiknas.

Wahyuni, R, N. (2016). Pengaruh pendidikan terhadap ketimpangan pendapatan tenaga kerja di Indonesia. Kependudukan Indonesia. 